\title{
PENERAPAN MODEL PEMBELAJARAN AUDITORY INTELLECTUALLY REPETITION TERHADAP KEMAMPUAN PEMAHAMAN KONSEP MATEMATIKA SISWA KELAS X
}

\author{
Siti Arofah \\ Fakultas Keguruan dan Ilmu Pendidikan, Universitas Pekalongan \\ email: sitiarofah9595@gmail.com
}

\begin{abstract}
The research was a quantitative research with experimental method. The population of research were all tenth grade students of SMAN 1 Wiradesa in the 2018/2019 academic year. The research was conducted to determine the effectiveness of the application of the Auditory Intellectually Repetition (AIR) learning model to the ability to understand mathematical concepts of Grade $X$ students of SMAN 1 Wiradesa. The results showed that the ability to understand mathematical concepts of students in classes taught using the AIR learning model achieved classical completeness, and the average value of the ability to understand mathematical concepts in the experimental class was better than the average value of the conceptual understanding ability in the control class. Based on these two results, it could be concluded that the application of the Auditory Intellectually Repetition learning model was effective on the ability to understand mathematical concepts of Grade X students of SMAN 1 Wiradesa.
\end{abstract}

Keywords: AIR, the Ability to Understand Mathematical Concepts

\section{PENDAHULUAN}

Matematika merupakan salah satu mata pelajaran wajib di semua jenjang sekolah. Matematika merupakan salah satu mata pelajaran yang penting untuk dipelajari di sekolah karena matematika banyak diterapkan dalam kehidupan sehari-hari. Berdasarkan Departemen Pendidikan Nasional dalam Permendiknas Nomor 22 Tahun 2006, salah satu tujuan mata pelajaran matematika untuk semua jenjang pendidikan dasar dan menengah adalah agar siswa mampu memahami konsep matematika, menjelaskan keterkaitan antarkonsep, dan mengaplikasikan konsep atau algoritma secara luwes, akurat, efisien, dan tepat, dalam pemecahan masalah. Hal ini menunjukkan bahwa pentingnya suatu pemahaman konsep dalam setiap pembelajaran matematika di sekolah.

Menurut Kilpatrick, Swafford, \& Findell (Afrilianto, 2012), pemahaman konsep (conceptual undestanding) merupakan kemampuan seseorang dalam memahami suatu konsep, operasi dan relasi dalam matematika. Adapun indikator yang menunjukkan bahwa siswa memiliki kemampuan pemahaman konsep menurut Kurikulum 2006 (Sipahutar \& Rahman, 2015) adalah: 1) menyatakan ulang sebuah konsep; 2) mengklasifikasikan objekobjek menurut sifat-sifat tertentu; 3) memberi contoh dan non contoh dari konsep; 4) menyajikan konsep dalam berbagai representasi matematis; 5) mengembangkan syarat perlu atau syarat cukup suatu konsep; 6) menggunakan, memanfaatkan, dan memilih prosedur atau operasi tertentu; dan 7) mengaplikasikan konsep atau algoritma pemecahan masalah.

Pemahaman konsep matematika menjadi sangat penting untuk dikembangkan oleh siswa karena pemahaman konsep matematika menjadi dasar bagi siswa dalam mengembangkan kemampuan matematika lainnya, namun masih ada sebagian siswa yang kurang memahami konsep matematika. Rendahnya kemampuan pemahaman konsep 
matematika siswa menyebabkan sebagian besar siswa kurang berminat dalam pembelajaran matematika.

Berdasarkan wawancara yang dilakukan kepada salah satu guru mata pelajaran matematika SMA Negeri 1 Wiradesa, sebagian besar siswa yang masih mengalami kesulitan dalam memahami konsep matematika. Hal tersebut didukung dengan nilai ratarata dari Penilaian Harian Bersama (PHB) mata pelajaran matematika semester I tahun ajaran 2018/2019 yang masih rendah. Sekitar 65\% siswa memperoleh nilai dibawah KKM. Siswa dikatakan tuntas dalam mata pelajaran matematika apabila siswa memperoleh nilai yang memenuhi KKM yaitu dengan nilai minimal 70.

Kemampuan pemahaman konsep matematika merupakan hal yang penting untuk dikembangkan dan harus dimiliki oleh siswa. Salah satu usaha untuk mengembangkan kemampuan pemahaman konsep matematika siswa adalah dengan pemilihan model pembelajaran yang tepat. Melihat model pembelajaran yang biasa digunakan oleh guru di SMA Negeri 1 Wiradesa yaitu model pembelajaran Small Group Discussion dimana dalam proses pembelajarannya masih berpusat pada guru dan siswa cenderung pasif dalam pembelajaran, maka diperlukan suatu penerapan model pembelajaran yang dapat mendorong siswa untuk aktif dalam pembelajaran matematika. Salah satu alternatif model pembelajaran yang dapat digunakan oleh guru adalah model pembelajaran Auditory Intellectually Repetition (AIR). Model pembelajaran Auditory Intellectually Repetition (AIR) sendiri merupakan salah satu model pembelajaran yang mempunyai peran dalam pembelajaran yaitu bahwa model ini baik untuk diterapkan dari sudut pandang kemampuan pemahaman konsep matematika siswa.

Model pembelajaran Auditory Intellectually Repetition (AIR) merupakan suatu model pembelajaran yang memandang bahwa suatu pembelajaran akan efektif apabila mempertimbangkan tiga hal, yaitu auditory, intellectually, dan repetition (Lestari \& Yudhanegara, 2018: 58). Menurut Suherman auditory memiliki arti bahwa belajar haruslah melalui kegiatan-kegiatan seperti mendengarkan, menyimak, berbicara, presentasi, argumentasi, mengemukakan pendapat, dan menanggapi (Shoimin, 2014: 29). Intellectually bermakna bahwa dalam belajar siswa harus menggunakan kemampuan berpikirnya (mind-on) melalui bernalar, menyelidiki, mengidentifikasi, menemukan, mencipta, memecahkan masalah, dan menerapkan (Shoimin, 2014: 29). Menurut Suherman repetition merupakan suatu pengulangan, dengan tujuan memperdalam dan memperluas pemahaman siswa (Shoimin, 2014: 29). Kegiatan pengulangan dapat dilakukan melalui pemberian tugas maupun kuis. Dengan melihat ketiga aspek tersebut, maka memungkinkan model pembelajaran Auditory Intellectually Repetition dapat diterapkan untuk melihat perkembangan kemampuan pemahaman konsep matematika siswa.

Berdasarkan uraian yang telah dikemukakan di atas, maka dilakukan suatu penelitian yang berjudul "Penerapan Model Pembelajaran Auditory Intellectually Repetition (AIR) Terhadap Kemampuan Pemahaman Konsep Matematika Siswa Kelas X SMAN 1 Wiradesa". Adapun rumusan masalah dalam penelitian ini adalah: "Apakah penerapan model pembelajaran Auditory Intellectually Repetition (AIR) efektif terhadap kemampuan pemahaman konsep matematika siswa kelas X SMA Negeri 1 Wiradesa?" Dari rumusan masalah tersebut, kemudian dijabarkan sebagai berikut:

1) Apakah kemampuan pemahaman konsep matematika siswa dengan menggunakan model pembelajaran Auditory Intellectually Repetition (AIR) dapat mencapai ketuntasan belajar?

2) Apakah kemampuan pemahaman konsep matematika siswa dengan menggunakan model pembelajaran Auditory Intellectually Repetition (AIR) lebih baik dari kemampuan pemahaman konsep matematika siswa dengan menggunakan model pembelajaran Small Group Discussion? 
Berdasarkan rumusan permasalahan yang telah diuraikan, maka tujuan penelitian ini adalah untuk mengetahui efektivitas penerapan model pembelajaran Auditory Intellectually Repetition (AIR) terhadap kemampuan pemahaman konsep matematika siswa kelas X SMA Negeri 1 Wiradesa. Selanjutnya, keberhasilan dari penelitian ini dilihat dari segi:

1) Hasil kemampuan pemahaman konsep matematika siswa dengan menggunakan model pembelajaran Auditory Intellectually Repetition (AIR) dapat mencapai ketuntasan belajar.

2) Hasil kemampuan pemahaman konsep matematika siswa dengan menggunakan model pembelajaran Auditory Intellectually Repetition (AIR) lebih baik dari hasil kemampuan pemahaman konsep matematika siswa dengan menggunakan model pembelajaran Small Group Discussion.

\section{METODE PENELITIAN}

Penelitian ini merupakan jenis penelitian kuantitatif dengan metode eksperimen. Desain penelitian yang digunakan, yaitu quasi experimental dengan bentuk the nonequivalent posttest-only control group design. Penelitian ini dilakukan di SMAN 1 Wiradesa pada tahun ajaran 2018/2019. Adapun pemilihan sampel menggunakan teknik cluster random sampling. Teknik cluster random sampling merupakan cara pengambilan sampel secara random yang didasarkan pada kelompok, tidak didasarkan pada anggotaanggotanya (Hikmawati, 2018: 65). Adapun sampel dalam penelitian ini adalah kelas X MIPA 4 sebagai kelas eksperimen dan kelas X MIPA 3 sebagai kelas kontrol. Teknik analisis data yang digunakan adalah uji ketuntasan belajar (uji proporsi) dan uji beda ratarata, dengan uji prasyarat yaitu uji normalitas dan uji homogenitas.

\section{HASIL DAN PEMBAHASAN}

Hasil dari posttest kemampuan pemahaman konsep matematika siswa kelas eksperimen dan kelas kontrol digunakan sebagai data akhir dapat dilihat pada Tabel 1 berikut ini.

Tabel 1 Hasil Posttest Kemampuan Pemahaman Konsep Matematika

\begin{tabular}{|l|c|c|c|c|}
\hline \multicolumn{1}{|c|}{ Kelas } & $\begin{array}{c}\text { Jumlah } \\
\text { Siswa }\end{array}$ & $\begin{array}{c}\text { Nilai } \\
\text { Tertinggi }\end{array}$ & $\begin{array}{c}\text { Nilai } \\
\text { Terendah }\end{array}$ & Rata-rata \\
\hline Eksperimen & 36 & 95 & 60 & 79,39 \\
\hline Kontrol & 35 & 83 & 53 & 70,09 \\
\hline
\end{tabular}

Berdasarkan Tabel 1 rata-rata hasil posttest kemampuan pemahaman konsep matematika siswa kelas eksperimen lebih tinggi daripada rata-rata hasil posttest kemampuan pemahaman konsep matematika siswa pada kelas kontrol. Pada kelas eksperimen nilai rata-rata posttest kemampuan pemahaman konsep matematika diperoleh 79,39 dan Pada kelas kontrol nilai rata-rata posttest kemampuan pemahaman konsep matematika diperoleh 70,09. Dilihat dari nilai rata-rata menunjukkan bahwa kemampuan pemahaman konsep matematika siswa kelas eksperimen lebih baik daripada kelas kontrol.

Data hasil dari posttest tersebut kemudian dianalisis uji normalitas untuk mengetahui bahwa data nilai kemampuan pemahaman konsep matematika siswa berdistribusi normal. Selain itu, data tersebut juga dianalisis uji homogenitas untuk mengetahui bahwa data kemampuan pemahaman konsep matematika siswa memiliki variansi yang sama. Setelah data kemampuan pemahaman konsep matematika dianalisis uji normalitas dan homogenitas, kemudian dilakukan uji ketuntasan belajar dan uji beda rata-rata. Uji ketuntasan belajar dilakukan untuk mengetahui bahwa proporsi ketuntasan belajar matematika siswa yang diterapkan model pembelajaran Auditory Intellectually Repetition (AIR) yang mendapat nilai $\geq 70$ lebih dari $69,9 \%$. Sedangkan uji beda rata-rata 
dilakukan untuk mengetahui bahwa nilai nilai rata-rata kemampuan pemahaman konsep matematika yang diwakili oleh siswa kelas eksperimen lebih dari nilai rata-rata kemampuan pemahaman konsep matematika yang diwakili oleh siswa kelas kontrol.

Hasil analisis data posttest dengan uji ketuntasan belajar kelas eksperimen dapat dilihat pada Tabel 2.

Tabel 2 Hasil Uji Ketuntasan Belajar

\begin{tabular}{|l|c|}
\hline \multicolumn{1}{|c|}{ Deskripsi } & $\begin{array}{c}\text { Kelas Eksperimen } \\
\text { (X MIPA 4) }\end{array}$ \\
\hline Jumlah siswa & 36 \\
\hline Jumlah siswa yang tuntas & 33 \\
\hline Proporsi ketuntasan belajar & $69,9 \%(0,699)$ \\
\hline$Z_{\text {hitung }}$ & 2,847 \\
\hline$Z_{\text {tabel }}$ & 1,645 \\
\hline Keterangan & $\mathrm{H}_{0}$ ditolak \\
\hline
\end{tabular}

Berdasarkan Tabel 2 diperoleh bahwa $Z_{\text {hitung }}=2,847$ dan $Z_{\text {tabel }}=1,645$ dengan jumlah siswa yang tuntas sebanyak 33 siswa. Karena nilai dari $Z_{\text {hitung }}>Z_{\text {tabel}}$, maka $\mathrm{H}_{0}$ ditolak dan $\mathrm{H}_{1}$ diterima, artinya bahwa proporsi ketuntasan belajar matematika siswa yang diterapkan model pembelajaran Auditory Intellectually Repetition yang mendapat nilai $\geq$ 70 lebih dari 69,9\%. Jadi dapat disimpulkan bahwa kemampuan pemahaman konsep matematikas siswa dengan menggunakan model pembelajaran Auditory Intellectually Repetition mencapai ketuntasan belajar secara klasikal. Hal tersebut sesuai dengan penelitian yang dilakukan oleh Handayani, Pujiastuti, \& Suhito (2014) yang menunjukkan bahwa kemampuan penalaran matematis siswa yang memperoleh pembelajaran dengan model pembelajaran Auditory Intellectually Reptition berbantuan LKPD dapat mencapai ketuntasan belajar secara klasikal yaitu $\geq 75 \%$.

Untuk mengetahui bahwa kemampuan pemahaman konsep matematika siswa kelas eksperimen lebih baik daripada kemampuan pemahaman konsep matematika siswa kelas kontrol, maka dilakukan uji beda rata-rata. Hasil analisis data posttest dengan uji beda ratarata dapat dilihat pada Tabel 3 berikut ini.

Tabel 3 Hasil Uji Beda Rata-rata

\begin{tabular}{|l|c|c|c|c|c|c|}
\hline \multicolumn{1}{|c|}{ Kelas } & $\begin{array}{c}\text { Jumlah } \\
\text { siswa }\end{array}$ & $\begin{array}{c}\text { Rata- } \\
\text { rata }\end{array}$ & $\begin{array}{c}\text { Standar } \\
\text { Deviasi }\end{array}$ & thitung & $\mathbf{t}_{\text {tabel }}$ & Keterangan \\
\cline { 1 - 5 } Eksperimen & 36 & 79,39 & \multirow{2}{*}{7,440} & 5,231 & 1,667 & $\mathrm{H}_{0}$ ditolak \\
\cline { 1 - 3 } Kontrol & 35 & 70,09 & & \\
\hline
\end{tabular}

Berdasarkan Tabel 3 diperoleh bahwa rata-rata kelas eksperimen dalah 79,39 dan rata-rata kelas kontrol adalah 70,09 dengan $t_{\text {hitung }}=5,231$ dan $t_{\text {tabel }}=1,667$. Sehingga nilai dari $\mathrm{t}_{\text {hitung }}>\mathrm{t}_{\text {tabel}}$, oleh karena itu $\mathrm{H}_{0}$ ditolak dan $\mathrm{H}_{1}$ diterima, artinya bahwa nilai nilai ratarata kemampuan pemahaman konsep matematika yang diwakili oleh siswa kelas eksperimen lebih dari nilai rata-rata kemampuan pemahaman konsep matematika yang diwakili oleh siswa kelas kontrol. Hal tersebut sesuai dengan penelitian yang dilakukan Hasnawati, Ikman, \& Sari (2016) yang menunjukkan bahwa hasil belajar matematika siswa dengan menggunakan model pembelajaran Auditory Intellectually Repetition (AIR) lebih baik dari hasil belajar matematika siswa dengan model pembelajaran langsung. Selain itu, Purnomo (2018) dalam penelitiannya menunjukkan bahwa rata-rata pemahaman konsep matematika dengan menggunakan model pembelajaran Auditory Intellectually Repetition (AIR) - Course Review Horay lebih tinggi daripada rata-rata pemahaman konsep matematika dengan menggunakan model pembelajaran konvensional. 
Penerapan Model Pembelajaran Auditory Intellectually Repetition Terhadap

Kemampuan Pemahaman Konsep Matematika Siswa Kelas X

Siti Arofah

\section{KESIMPULAN}

Berdasarkan hasil dan pembahasan maka dapat disimpulkan bahwa penerapan model pembelajaran Auditory Intellectually Repetition (AIR) efektif terhadap kemampuan pemahaman konsep matematika siswa kelas X SMAN 1 Wiradesa, hal ini dapat dilihat sebagai berikut:

1. Kemampuan pemahaman konsep matematika siswa pada kelas yang diterapkan model pembelajaran Auditory Intellectually Repetition mencapai ketuntasan belajar secara klasikal.

2. Kemampuan pemahaman konsep matematika siswa pada kelas yang diterapkan model pembelajaran Auditory Intellectually Repetition lebih baik daripada kemampuan pemahaman konsep matematika siswa pada kelas yang diterapkan model pembelajaran Small Group Discussion.

\section{REFERENSI}

Afrilianto, M. 2012. Peningkatan Pemahaman Konsep dan Kompetensi Strategis Matematis Siswa SMP dengan Pendekatan Metaphorical Thinking. Infinity Volume 1 (September 2012) Nomor 2. Electronic Edition ISSN 2460-9285. Diunduh di http://e-journal.stkipsiliwangi.ac.id/index.php/infinity/article/view/19, pada 21 Maret 2019.

Departemen Pendidikan Nasional. 2006. Permendiknas Nomor 22 Tahun 2006 tentang Standar Isi. Jakarta: Depdiknas.

Handayani, I.M., Pujiastuti, E., \& Suhito. 2014. Keefektifan Auditory Intellectually Repetition Berbantuan LKPD terhadap Kemampuan Penalaran Peserta Didik SMP. Kreano Volume 5 (Juni 2014) Nomor 1. Electronic Edition ISSN 2442-4218. Diunduh di https://journal.unnes.ac.id/nju/index.php/kreano/article/view/ 3271/3216, pada 11 Desember 2018.

Hasnawati, Ikman, \& Sari, A. 2016. Effectiveness Model of Auditory Intellectually Repetition (AIR) to Learning Outcomes of Math Students. International Journal of Education and Research Volume 4 (May 2016) Number 5. Electronic Edition ISSN 2411-5681. Diunduh di https://www.ijern.com/journal/2016/May-2016/22.pdf, pada 7 Februari 2019.

Hikmawati, F. 2018. Metodologi Penelitian. Depok: RajawaliGrafindo Persada.

Lestari, K.E. \& Yudhanegara, M.R. 2018. Penelitian Pendidikan Matematika. Bandung: PT Refika Aditama.

Purnomo, B. 2018. Pemahaman Konsep Matematika Siswa Melalui Model Pembelajaran AIR (Auditory, Intellectually, Repetition) dan Course Review Horay. Soulmath Volume 6 (Maret 2018) Nomor 1. Electronic Edition ISSN 2581-1290. Diunduh di https://ejournal.unitomo.ac.id/index.php/mipa/article/view/376/474, pada 7 Februari 2019.

Shoimin, A. 2014. 68 Model Pembelajaran Inovatif dalam Kurikulum 2013. Yogyakarta: Ar-Ruzz Media.

Sipahutar, H.M. dan Rahman, A.A. 2015. Perbandingan Kemampuan Pemahaman Konsep Matematika Siswa Menggunakan Model Pembelajaran Kooperatif Tipe Student Teams Achievement Division (STAD) dengan Team Game Tournament (TGT) di SD Islam Khalifah Annizam. Bina Gogik Volume 2 Nomor 1. Electronic Edition ISSN 2579-874X. Diunduh di https://ejournal.stkipbbm.ac.id/index.php/pgsd/article/ view/87/77, pada 28 November 2018 . 